\title{
Development of SCAR Markers and an SYBR Green Assay to Detect Puccinia striiformis f. sp. tritici in Infected Wheat Leaves
}

L. Gao, State Key Laboratory for Biology of Plant Disease and Insect Pests, Institute of Plant Protection, Chinese Academy of Agricultural Sciences, Beijing 100193, P. R. China; H. X. Yu and X. H. Kang, School of Life Science and Engineering, Southwest University of Science and Technology, Sichuan 621000, P. R. China; and H. M. Shen, C. Li, T. G. Liu, B. Liu, and W. Q. Chen, State Key Laboratory for Biology of Plant Disease and Insect Pests, Institute of Plant Protection, Chinese Academy of Agricultural Sciences, Beijing 100193, P. R. China

\begin{abstract}
Gao, L., Yu, H. X, Shen, H. M., Li, C., Liu, T. G., Liu, B., Kang, X. H., and Chen, W. Q. 2016. Development of SCAR markers and an SYBR green assay to detect Puccinia striiformis f. sp. tritici in infected wheat leaves. Plant Dis. 100:1840-1847.

Stripe rust, caused by the pathogenic fungus Puccinia striiformis $\mathrm{f}$. sp. tritici, is an important disease of wheat worldwide. A rapid and reliable detection of the pathogen in latent infected wheat leaves is useful for accurate and early forecast of outbreaks and timely application of fungicides for managing the disease. Using the previously reported primer pair $\mathrm{Bt} 2 \mathrm{a} / \mathrm{Bt} 2 \mathrm{~b}$, a 362-bp amplicon was obtained from $P$. striiformis f. sp. tritici and a 486-bp amplicon was obtained from both $P$. triticina (the leaf rust pathogen) and $P$. graminis $\mathrm{f}$. sp. tritici (the stem rust pathogen). Based on the sequence of the 362-bp fragment, two pairs of sequence characterized amplified region (SCAR) primers were designed. PSTF117/PSTR363 produced a 274-bp amplicon and TF114/TR323

produced a 180-bp amplicon from $P$. striiformis f. sp. tritici, whereas they did not produce any amplicon from $P$. triticina, $P$. graminis $\mathrm{f}$. $\mathrm{sp}$. tritici, or any other wheat-infecting fungi. The detection limit of PSTF117/PSTR363 was $1 \mathrm{pg} / \mu \mathrm{l}$ and TF114/TR323 was $100 \mathrm{fg} / \mu \mathrm{l}$. Both SCAR markers could be detected in wheat leaves $9 \mathrm{~h}$ post inoculation. An SYBR Green RT-PCR method was also developed to detect $P$. striiformis $\mathrm{f}$. sp. tritici in infected leaves with the detection limit of $1.0 \mathrm{fg}$ DNA from asymptomatic leaf samples of $6 \mathrm{~h}$ after inoculation. These methods should be useful for rapid diagnosis and accurate detection of $P$. striiformis $\mathrm{f}$. $\mathrm{sp}$. tritici in infected wheat leaves for timely control of the disease.
\end{abstract}

Wheat rusts, including stripe rust caused by Puccinia striiformis Westend. f. sp. tritici Erikss., leaf rust caused by P. triticina Erikss., and stem rust caused by $P$. graminis Pers.:Pers. f. sp. tritici Erikss. \& E. Henn., are destructive diseases in China and most other wheat growing countries. The occurrence of the three distinct rust diseases in different countries or regions of the world varies in terms of type, distribution, and degree of damage (Chen 2005; Chen et al. 2014; Kutschera and Hossfeld 2012).

Among the three rusts, stripe rust is the most important in China (Wan et al. 2007). Epidemics of this disease occurred in 1950, 1964,1990 , and 2002 , causing up to $6.0 \times 10^{9}, 3.0 \times 10^{9}, 2.6 \times 10^{9}$, and $1.0 \times 10^{9} \mathrm{~kg}$ of yield losses, respectively (Chen et al. 2009; Wan et al. 2004). Due to the development of prevalent races of the pathogen (CYR32 and CYR33), 80\% of commercially grown wheat cultivars in China have become susceptible to stripe rust (Chen et al. 2009). For each of the nine years from 2001 to 2009, stripe rust epidemics occurred in southwestern and northwestern China (Chen et al. 2009), making this disease a major problem for sustainable wheat production in the country.

Stripe rust causes reduction of grain yield and quality in China, and more than 20 million ha of wheat can be affected (Chen et al. 2014; Wellings 2011). Seeds harvested from crops infected by $P$. striiformis f. sp. tritici have poor germination and low plant vigor, leading to low winter survival. Urediniospores of the fungal pathogen are spread in long distance by winds (Chen 2005). In China, forecasts of wheat rusts have long been based on periodic large-scale field surveys and isolation of pathogens, as well as identification of races on living

Corresponding author: L. Gao; E-mail: xiaogaosx@hotmail.com

*The $\boldsymbol{e}$-Xtra logo stands for "electronic extra" and indicates that three supplementary figures are available online.

Accepted for publication 16 November 2015.

http://dx.doi.org/10.1094/PDIS-06-15-0693-RE

(C) 2016 The American Phytopathological Society plants under controlled conditions. This work is not only timeconsuming and laborious but also has limited accuracy and reliability. It is largely dependent on the skill level and experience of the investigation and forecasting staff, and thus it is hard to meet the demand for rapid, high-throughput detection and early, accurate forecasts (Gao et al. 2008, 2013). Therefore, it is necessary to take advantage of modern biotechnology for developing simple, sensitive, and accurate methods of rapid detection of $P$. striiformis f. sp. tritici.

In recent years, with the development of real-time PCR techniques, specific PCR primers or probes targeting specific gene sequences have been increasingly used in research on the biology, population structure, epidemiology, and genetic diversity of plant pathogens. For disease diagnosis and pathogen identification, target sequences are commonly obtained by sequence comparison of conserved genes or random exploration of chromosomal sequences (McCartney et al. 2003). PCR techniques are characterized by strong specificity, high sensitivity, and programed operation, which have been widely used for molecular identification and detection of a variety of plant pathogens (Arif et al. 2014; Beck and Ligon 1995; Demers et al. 2015; Fan et al. 2015; Frederick et al. 2000; Johanson et al. 1998; Moricca et al. 1998; Mutasa et al. 1996; Schilling et al. 1996; Sreenivasaprasad et al. 1996; Sun et al. 2015; Willits and Sherwood 1998). In view of the limitations of symptomatic diagnosis and the complexity of morphological identification, PCR-based methods for rapid diagnosis and detection of three wheat rust diseases have been reported. For example, Cao et al. (2007, 2008) established a PCR-based technique for specific molecular diagnosis and detection of $P$. striiformis $\mathrm{f}$. sp. tritici and $P$. triticina by targeting $\beta$-tubulin sequence. Wang et al. $(2008,2009)$ established common PCR and nested PCR detection methods for directly identifying $P$. striiformis f. sp. tritici in infected wheat leaves based on a genomespecific sequence. Pan et al. (2010) established a SCAR marker and RT-PCR to detect latent infection of wheat stripe rust based on $\beta$-tubulin sequences. Barnes and Szabo (2007) employed RT-PCR technique targeting the ITS1 sequence to establish a molecular detection method of the three pathogenic Puccinia species. These methods are based on nucleic acid technologies that detect specific DNA 
sequences in the genome of pathogens, involving sample extraction, PCR amplification, and analysis of PCR products. The PCR-based techniques have relatively high accuracy and reliability for relevant disease diagnosis and pathogen detection.

In the present study, a comparative PCR analysis was conducted using the conserved region of $\mathrm{Bt} 2 \mathrm{a}$ and $\mathrm{Bt} 2 \mathrm{~b}$ as primers and genomic DNA of $P$. striiformis f. sp. tritici, $P$. triticina, and $P$. graminis $\mathrm{f}$. $\mathrm{sp}$. tritici as templates, in order to obtain specific PCR primers and SCAR markers for molecular diagnosis, detection, and investigation of $P$. striiformis f. sp. tritici in wheat. We developed more sensitive SCAR markers and an SYBR Green assay for detection and diagnosis of $P$. striiformis $\mathrm{f}$. sp. tritici in infected wheat leaves.

\section{Materials and Methods}

Propagation and preservation of fungal pathogens. Urediniospores of $P$. striiformis f. sp. tritici (CYR33, CYR32), P. triticina (PHT, THT), and $P$. graminis f. sp. tritici (21C3, 34C2) were propagated on the susceptible wheat cultivar Mingxian 169 as described by Cao et al. (2008), whereas Blumeria graminis (the wheat powdery mildew pathogen) was propagated by hyphae and conidia on wheat cultivar Zhengmai 5389. Other fungal pathogens of wheat were cultured on potato dextrose agar (PDA).
Extraction of fungal genomic DNA. Genomic DNA was extracted from wheat pathogens using the method of Villareál et al. (2002), with slight modifications on grinding in liquid nitrogen instead of vortex. For Puccinia species and B. graminis, DNA was extracted from infected wheat leaves with urediniospores or conidia. As for the other wheat pathogens, DNA was extracted from vegetative hyphae. Infected wheat leaves or vegetative hyphae were directly frozen in liquid nitrogen and then ground to fine powder. Puccinia and $B$. graminis spores were disrupted by shaking of glass beads. The procedures of Villareál et al. (2002) was followed for the other steps of DNA extraction, such as extracted with chloroform, added cold isopropanol, centrifuged, washed with ethanol, and dissolved in TE buffer, and after RNA digestion with $10 \mu \mathrm{l}(10 \mathrm{mg} / \mathrm{ml})$ RNase at $37^{\circ} \mathrm{C}$ for $1 \mathrm{~h}$, the extracted DNA was qualified and quantified using a UV spectrophotometer.

Comparative PCR analysis and sequencing of the DNA fragment from $P$. striiformis f. sp. tritici. PCR was performed in a MJ Research PTC-220 Thermal Cycler (MJ Research Inc., Waltham, MA). The primers were Bt2a (forward): $5^{\prime}$-GGTAACCAAATCGG TGCTGCTTTC-3', and Bt2b (reverse): 5'-ACCCTCAGTGTAGT GACCCTTGGC-3' (Glass and Donaldson 1995). The PCR reactions for comparative amplification with DNA from $P$. striiformis f. sp. tritici,

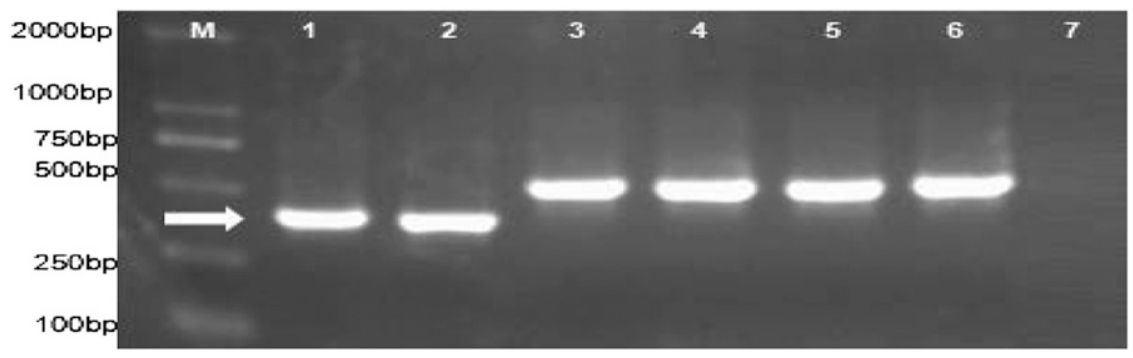

Fig. 1. Specific DNA fragment from Puccinia striiformis f. sp. tritici with primer pair of Bt2a/Bt2b. Lanes 1-2, isolates CYR33 and CYR32 of $P$. striiformis f. sp. tritici. Lanes $3-4$, $P$. triticina isolates PHT and THT. Lanes 5-6, P. graminis f. sp. tritici isolates $21 \mathrm{C} 3$ and 34C2. Lane 7, $\mathrm{ddH}_{2} \mathrm{O}$ as control, and M, marker DL2000 marked with fragment sizes in base pair (bp). The specific band is marked with an arrow.

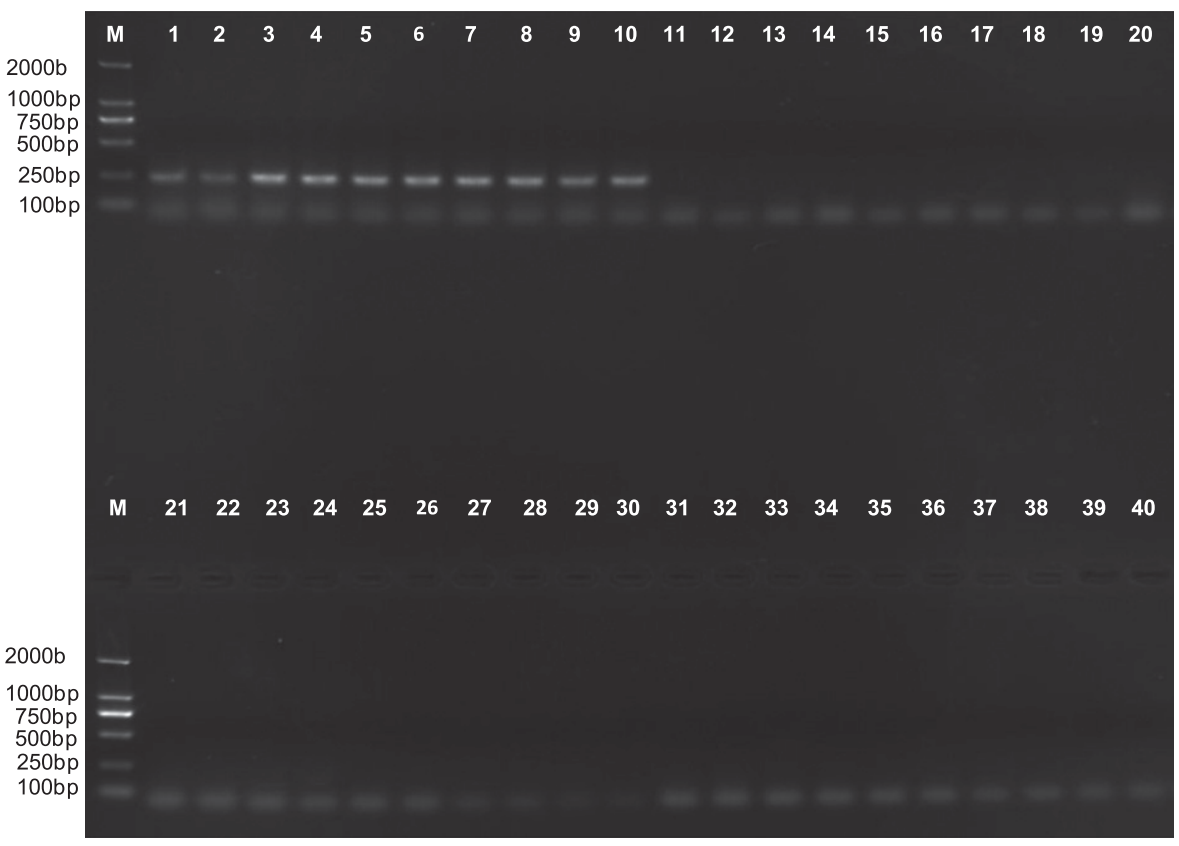

Fig. 2. Specificity for detection of $P$. striiformis f. sp. tritici with primer pair of PSTF117/PSTR363. Lanes 1-10, isolates of $P$. striiformis f. sp. tritici. Lanes 11-16, isolates of $P$. triticina. Lanes 17-22, isolates of $P$. graminis f. sp. tritici. Lanes 23-24, isolates of Blumeria graminis. Lanes 25-26, isolates of Fusarium graminearum. Lanes 27-28, isolates of Tilletia caries. Lane 29, isolate of $T$. foetida. Lane 30, isolate of $T$. controversa. Lanes 31, isolate of Helminthosporium tritici-repentis. Lane 32, isolate of $F$. nivale. Lane 33, isolate of Ustilago tritici. Lane 34, isolate of Claviceps purpurea. Lanes 35, isolate of Bipolaris sorokiniana. Lane 36, isolate of Gaeumnnomyces gramins. Lane 37, isolate of Colletotrichum graminicola. Lane 38, isolate of Pseudocercosporella herpotrichoides. Lane 39, isolate of Sclerophthora macrospora var. triticina. Lane 40 , ddH $\mathrm{O}_{2} \mathrm{O}$ as control, and $\mathrm{M}$, marker DL1000 marked with fragment sizes in base pair (bp). 
P. triticina, and $P$. graminis contained $(25 \mu \mathrm{l}): 2.0 \mu \mathrm{l}$ of $10 \times \mathrm{PCR}$ Buffer $\left(\mathrm{Mg}^{2+}\right.$ Plus), $0.3 \mu \mathrm{l}$ of dNTP mixture (2.5 mM each), $1.0 \mu \mathrm{l}$ of Bt2a and $1.0 \mu \mathrm{l}$ of Bt $2 \mathrm{~b}$ primers $(10 \mu \mathrm{M}), 1.0 \mu \mathrm{l}$ of DNA template (20 ng/ $\mu \mathrm{l}), 0.3 \mu \mathrm{l}$ of TaKaRa Taq $(5 \mathrm{U} / \mu \mathrm{l})$, and $19.4 \mu \mathrm{l}$ of $\mathrm{ddH}_{2} \mathrm{O}$. The PCR conditions were as follows: one cycle of predegeneration at $94^{\circ} \mathrm{C}$ for $2 \mathrm{~min}$, followed by 30 cycles of degeneration at $94^{\circ} \mathrm{C}$ for $15 \mathrm{~s}$, annealing at $55^{\circ} \mathrm{C}$ for $30 \mathrm{~s}$, and extension at $72^{\circ} \mathrm{C}$ for $90 \mathrm{~s}$, with a final step of extension at $72^{\circ} \mathrm{C}$ for $10 \mathrm{~min}$.

The PCR products were checked on $1.5 \%$ agarose gel and separated by electrophoresis in $0.5 \times$ TBE buffer. Specific DNA band amplified from DNA of $P$. striiformis f. sp. tritici was immediately excised from agarose gel under UV light and purified using a Catcher Spin in GEK2050 gel extraction kit (Yinuojin Biotech, Shenzhen, Guangdong, China). The purified DNA was sent to Shenggong Biotech (Shanghai, China) for bidirectional sequencing, and the obtained sequences were assembled using NCBI BLAST. The full-length specific PCR fragment was used for similarity comparison with sequences in the databases of GenBank, EMBL, DDBJ, and PDB using the BLASTn program.
Development of SCAR markers for $\boldsymbol{P}$. striiformis f. sp. tritici. Based on the full-length sequence of the specific PCR fragment from $P$. striiformis f. sp. tritici, specific SCAR primers were designed using Primer 5.0 software and then synthesized by SBS Genetech Co., Ltd., Beijing, China. The PCR reaction and amplification conditions were further optimized to obtain specific SCAR markers for P. striiformis f. sp. tritici. Serially diluted template DNA of $P$. striiformis f. sp. tritici was PCR-amplified to examine the detection sensitivity of the designed SCAR marker. The specificity of the SCAR marker for detection of $P$. striiformis f. sp. tritici was determined using $P$. striiformis f. sp. tritici standard samples from different wheat-growing areas of China, with other wheat pathogens including $P$. triticina, $P$. graminis f. sp. tritici, B. graminis, Fusarium graminearum, Tilletia foetida, T. caries, T. controversa, Helminthosporium tritici-repentis, Fusarium nivale, Ustilago tritici, Claviceps purpurea, Bipolaris sorokiniana, Gaeumnnomyces graminis, Colletotrichum graminicola, Oculimacula yallundae (syn. Pseudocercosporella herpotrichoides), and Sclerophthora macrospora var. triticina.

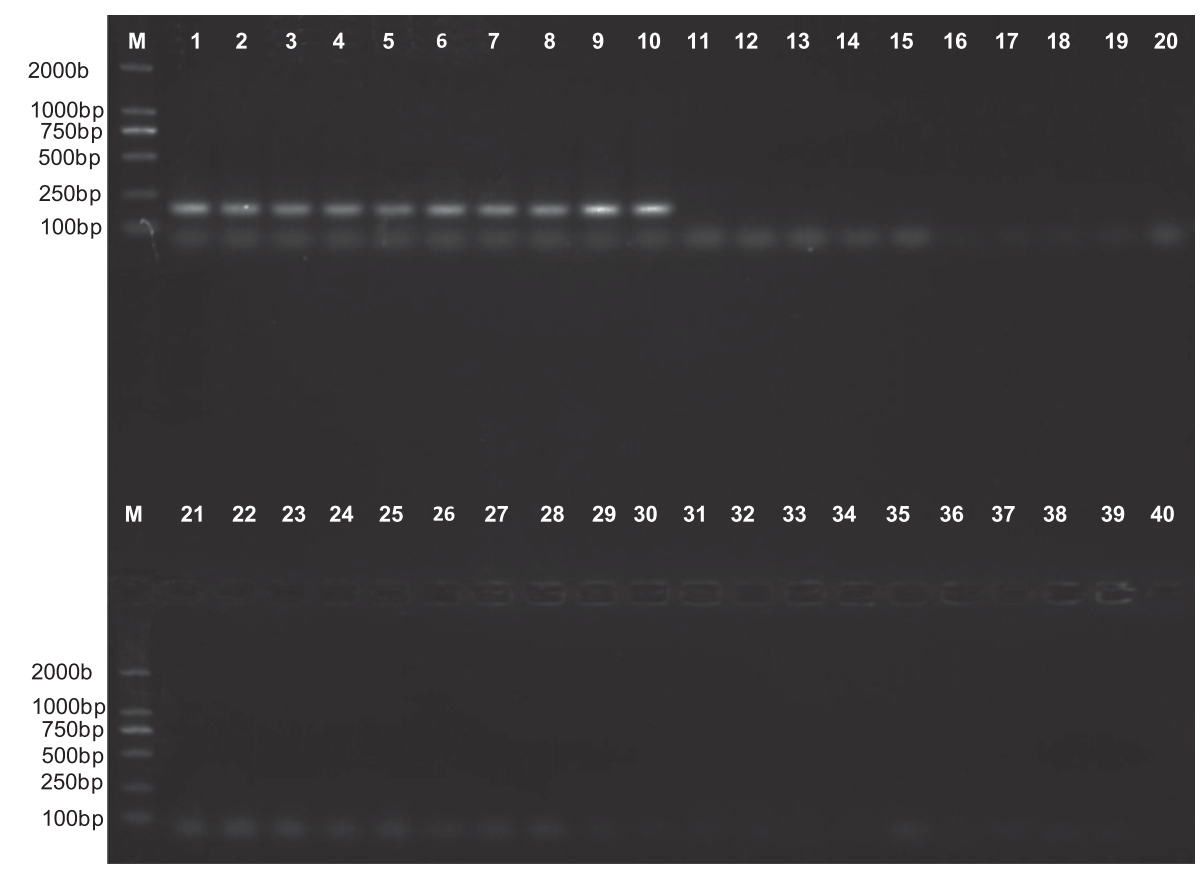

Fig. 3. Specificity for detection of $P$. striiformis $\mathrm{f}$. sp. tritici with primer pair of TF144/TR323. Lanes 1-10, isolates of $P$. striiformis f. sp. tritici. Lanes 11-16, isolates of $P$. triticina. Lanes 17-22, isolates of $P$. graminis f. sp. tritici. Lanes 23-24, isolates of $B$. graminis. Lanes 25-26, isolates of $F$. graminearum. Lanes 27-28, isolates of $T$. caries. Lane 29, isolate of $T$. foetida. Lane 30, isolate of $T$. controversa. Lanes 31, isolate of $H$. tritici-repentis. Lane 32, isolate of $F$. nivale. Lane 33, isolate of $U$. tritici. Lane 34, isolate of $C$. purpurea. Lanes 35 , isolate of $B$. sorokiniana. Lane 36, isolate of G. gramins. Lane 37, isolate of $C$. graminicola. Lane 38, isolate of $P$. herpotrichoides. Lane 39, isolate of $S$. macrospora var. triticina. Lane $40, \mathrm{ddH}_{2} \mathrm{O}$ as control, and M, marker DL1000 marked with fragment sizes in base pair (bp).

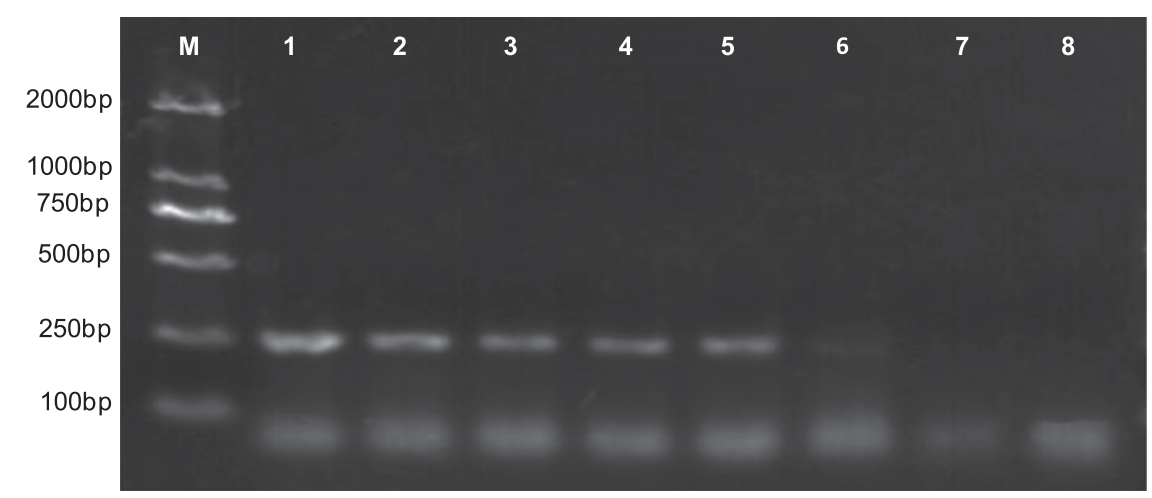

Fig. 4. Sensitivity with primer pair of PSTF117/PSTR363. Template DNA of $P$. striiformis f. sp. tritici in lanes $1-8,10.0 \mathrm{ng} / \mu \mathrm{l}$ (lane 1$), 1.0 \mathrm{ng} / \mu \mathrm{l}(\mathrm{lane} 2), 100.0 \mathrm{pg} / \mu \mathrm{l}(\mathrm{lane} 3), 10.0 \mathrm{pg} / \mu \mathrm{l}$ (lane 4), $1.0 \mathrm{pg} / \mu \mathrm{l}$ (lane 5), $100.0 \mathrm{fg} / \mu \mathrm{l}$ (lane 6), $10.0 \mathrm{fg} / \mu \mathrm{l}$ (lane 7), $\mathrm{ddH}_{2} \mathrm{O}$ (lane 8), and M, marker DL1000 marked with fragment sizes in base pair (bp). 
Detection of $P$. striiformis f. sp. tritici in infected wheat leaves. Urediniospores of $P$. striiformis f. sp. tritici mixed with talc were inoculated on seedlings of Mingxian 169 under greenhouse conditions, with talc sprayed to plants of the control treatment. Samples of wheat leaves were collected at 3, 6, 9, 12, 20, 24, 48, 72, 96, and $120 \mathrm{~h}$ after inoculation for detection of $P$. striiformis $\mathrm{f}$. sp. tritici before the symptoms of stripe rust appeared. The surface of leaf samples was washed with sterile water, immediately frozen in liquid nitrogen, and stored at $-80^{\circ} \mathrm{C}$ before use.

SYBR Green RT-PCR detection. The fluorescent-based SYBR Green was used in the RT-PCR experiment. The primer pair $\left(5^{\prime}-\right.$ GGATGCCTCGAAGGGTTATACC-3'/5'-TGCTAGATACAATGG CACATCTGA-3') was designed using the Primer 5.0 software and synthesized by Shanghai Shenggong Biological Engineering Technology and Service Co., Ltd., China.

For SYBR Green, the PCR reaction was performed in $20 \mu \mathrm{l}$ reaction mixture containing $2 \times$ SG Green qPCR Mix $10 \mu \mathrm{l}$ (SinoGene, Beijing, China), $0.5 \mu l$ of primers $(10 \mu \mathrm{M})$, and $1.0 \mu \mathrm{l}$ of DNA sample. The ABI7500 was used with the following program: $95^{\circ} \mathrm{C}$ for $10 \mathrm{~min}, 45$ cycles each at $95^{\circ} \mathrm{C}$ for $20 \mathrm{~s}$, and $60^{\circ} \mathrm{C}$ for $30 \mathrm{~s}$. The fluorescent signal was collected at the annealing step and the extending step $\left(60^{\circ} \mathrm{C}\right.$ for $\left.30 \mathrm{~s}\right)$ of each cycle. Samples of wheat leaves were collected as mentioned above.

\section{Results}

Comparative PCR analysis and sequencing of the specific DNA fragment from $\boldsymbol{P}$. striiformis f. sp. tritici. Using the primer set $\mathrm{Bt} 2 \mathrm{a}$ and $\mathrm{Bt} 2 \mathrm{~b}$, a 362-bp fragment was amplified from $P$. striiformis f. sp. tritici, while a 496-bp fragment was amplified from both $P$. triticina and $P$. graminis f. sp. tritici (Fig. 1). The DNA fragments of $P$. triticina and $P$. graminis f. sp. tritici shared $100 \%$ homology, whereas the specific DNA fragment of $P$. striiformis $\mathrm{f}$. sp. tritici shared only $31.23 \%$ homology with the sequences of $P$. triticina or $P$. graminis f. sp. tritici (Supplementary Figs. S1 and S2).

Amplification of SCAR marker. Based on the PCR fragment sequences of the three Puccinia species, two pairs of primers were designed: PSTF117 (forward): 5'-CACGCGGGACGTACTTATTG TC-3'; PSTR363 (reverse): 5'-CATTTCTGGCGAACATGGAATC-3'; TF144 (forward): 5'-CCTGCGATGGTGTAGACTCA-3'; and TR323 (reverse): 5'-CGGCGTGTATGTTCGTGTTG-3'. Further, the parameters of PCR detection were optimized. The $25 \mu \mathrm{l}$ reaction contained $1.0 \mu \mathrm{l}$ of PSTF117/PSTR363 (TF144/TR323) $(10 \mu \mathrm{M}), 1.0 \mu \mathrm{l}$ of

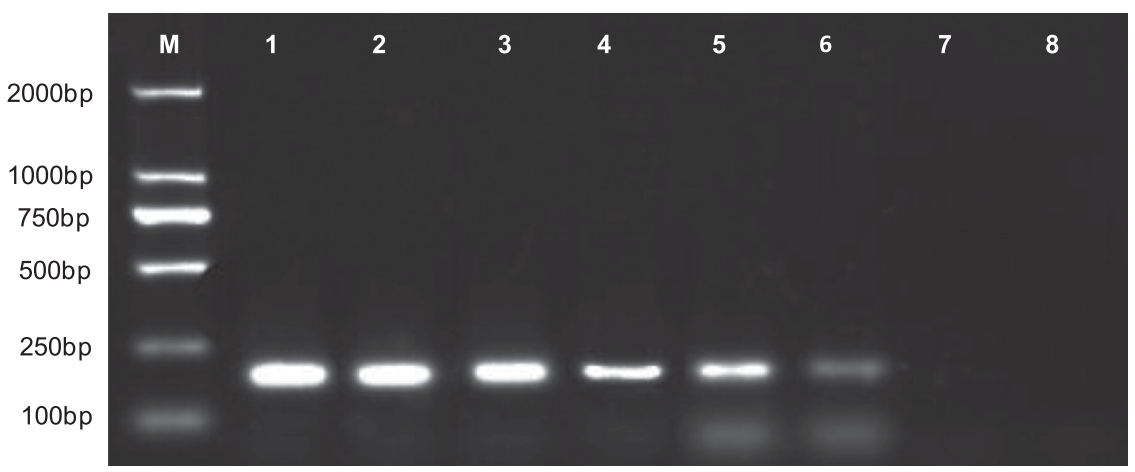

Fig. 5. Sensitivity with primer pair of TF144/TR323. Template DNA of $P$. strifformis f. sp. tritici in lanes $1-8,10.0 \mathrm{ng} / \mu \mathrm{l}(\mathrm{lane} 1), 1.0 \mathrm{ng} / \mu \mathrm{l}(\mathrm{lane} 2), 100.0 \mathrm{pg} / \mu \mathrm{l}$ (lane 3 ), $10.0 \mathrm{pg} / \mu \mathrm{l}$ (lane 4), $1.0 \mathrm{pg} / \mu \mathrm{l}$ (lane 5), $100.0 \mathrm{fg} / \mu \mathrm{l}$ (lane 6), $10.0 \mathrm{fg} / \mu \mathrm{l}$ (lane 7), $\mathrm{ddH}_{2} \mathrm{O}$ (lane 8), and M, marker DL1000 marked with fragment sizes in base pair (bp).

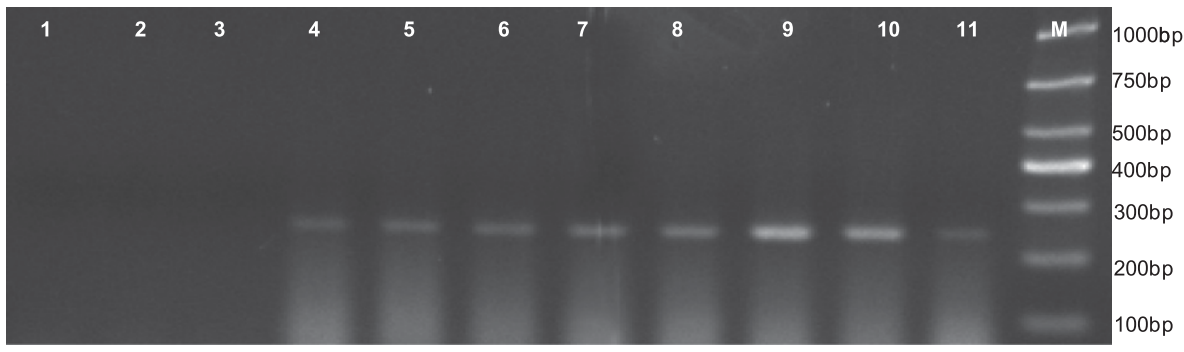

Fig. 6. Detection of $P$. striiformis $\mathrm{f}$. sp. tritici in infected wheat leaves with primer pair of PSTF117/PSTR363. Lane 1, $\mathrm{ddH}_{2} \mathrm{O}$. Lanes 2-11, template DNA of leaf samples were taken at $3,6,9,12,20,24,48,72,96$, and $120 \mathrm{~h}$ after inoculation, and M, marker DL1000 marked with fragment sizes in base pair (bp).

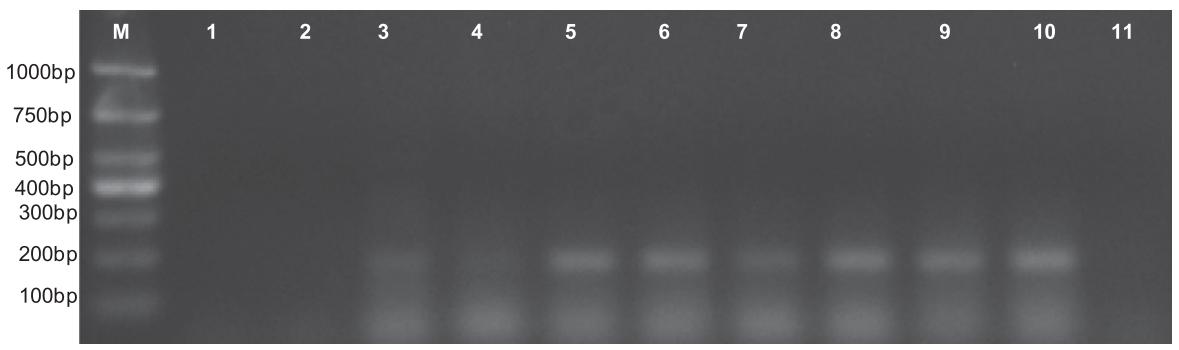

Fig. 7. Detection of $P$. striiformis f. sp. tritici in infected wheat leaves with primer pair of TF144/TR323. Lane 11, $\mathrm{ddH}_{2} \mathrm{O}$. Lanes 1-10, template DNA of leaf samples were taken at 3,6 , 9, 12, 20, 24, 48, 72, 96, and $120 \mathrm{~h}$ after inoculation; and M, marker DL1000 marked with fragment sizes in base pair (bp). 
template DNA (20 ng/ $\mu \mathrm{l}), 2 \times$ EasyTaq PCR SuperMix $12.5 \mu \mathrm{l}$ (TransGen Biotech, Beijing, China), and $\mathrm{ddH}_{2} \mathrm{O} 9.5 \mu$ l. The PCR conditions were as follows: $94^{\circ} \mathrm{C}$ for $4 \mathrm{~min}$, followed by 35 cycles of $94^{\circ} \mathrm{C}$ for $30 \mathrm{~s}, 55.5^{\circ} \mathrm{C}$ for PSTF117/PSTR363 (or $54.5^{\circ} \mathrm{C}$ for TF144/TR323), $30 \mathrm{~s}$, and $72^{\circ} \mathrm{C}$ for $60 \mathrm{~s}$, and a final step of $72^{\circ} \mathrm{C}$ for $8 \mathrm{~min}$.
The primer set PSTF117/PSTR363 produced a 237-bp SCAR marker and TF144/TR323 produced a 180-bp SCAR marker. The markers were tested with other major races of $P$. striiformis $\mathrm{f}$. $\mathrm{sp}$. tritici $i$ and other major wheat fungal pathogens ( $P$. triticina, $P$. graminis f. sp. tritici, B. graminis, F. graminearum, T. foetida, T. caries, T. controversa, $H$. tritici-repentis, F. nivale, U. tritici, C. purpurea,

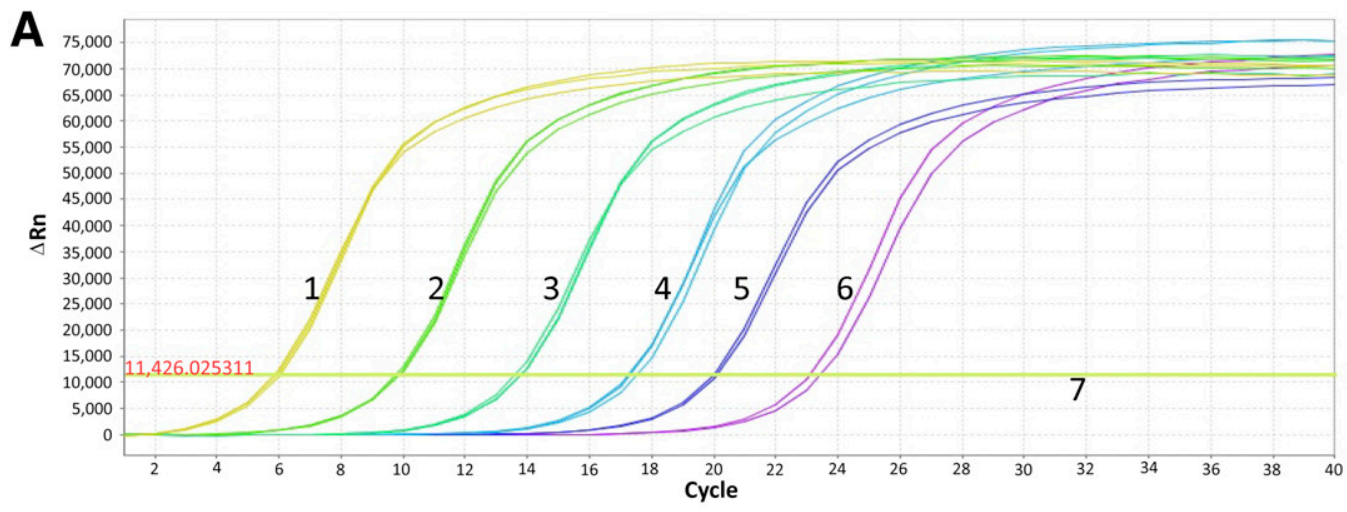

B

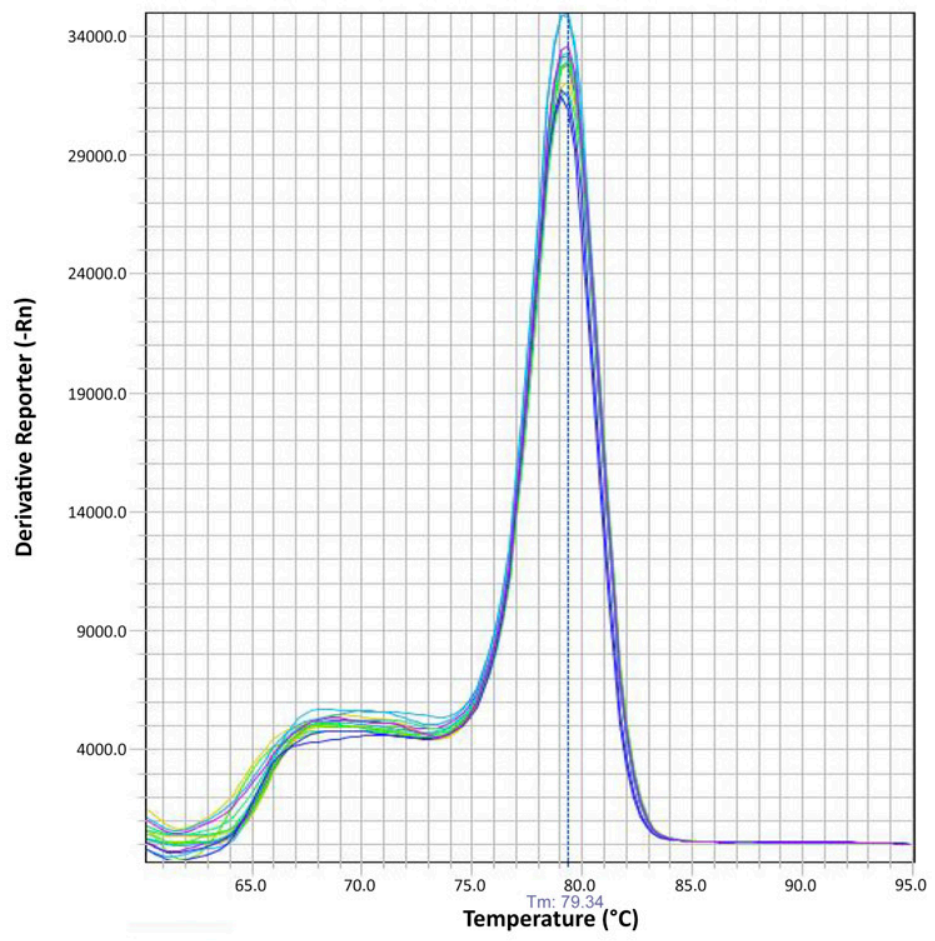

C

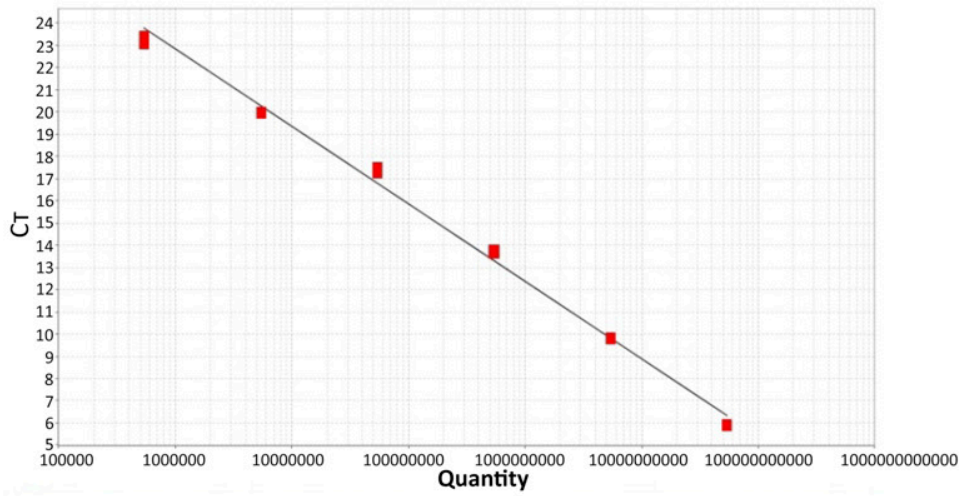

Target: Target 1Slope: -3.479 Y-Inter: $43.755 \underline{\mathrm{R}^{2}}$ : 0.994 Eff\%: 93.842

Fig. 8. Construction of $P$. striiformis f. sp. tritici standard curve by SYBR Green real-time PCR. A, Real-time amplified curves. 1-6, Ten-fold dilutions of recombined plasmid DNA $(0.1 \mathrm{ng}$ to $1.0 \mathrm{fg}) ; 7$ negative control. B, Melt curve of SYBR Green I (peak temperature at $\left.79.34^{\circ} \mathrm{C}\right)$. C, Standard curve. 
B. sorokiniana, G. gramins, C. graminicola, P. herpotrichoides, and $S$. macrospora var. triticina). The expected amplicons were obtained in all samples of $P$. striiformis f. sp. tritici but not in any of the other pathogen samples (Figs. 2 and 3 ).

Sensitivity of the SCAR markers. Template DNA of $P$. striiformis f. sp. tritici was prepared in serial dilutions $(20.0 \mathrm{ng} / \mu \mathrm{l}$, $10.0 \mathrm{ng} / \mu \mathrm{l}, 1.0 \mathrm{ng} / \mu \mathrm{l}, 100.0 \mathrm{pg} / \mu \mathrm{l}, 10.0 \mathrm{pg} / \mu \mathrm{l}, 1.0 \mathrm{pg} / \mu \mathrm{l}, 100.0 \mathrm{fg} / \mu \mathrm{l}$, $10.0 \mathrm{fg} / \mu \mathrm{l}$, and $1.0 \mathrm{fg} / \mu \mathrm{l}$ ) and amplified using PSTF117/PSTR363 or TF144/TR323. The former primer set consistently amplified the 237-bp fragment in the $1.0 \mathrm{pg} / \mu \mathrm{l}$ DNA template and the later set amplified the 180-bp fragment in the $100.0 \mathrm{fg} / \mu \mathrm{l}$ DNA template (Figs. 4 and 5).
PCR detection of $P$. striiformis $\mathrm{f}$. sp. tritici in infected wheat leaves. With both PSTF117/PSTR363 and TF144/TR323 primer sets, the expected SCAR markers of $P$. striiformis $\mathrm{f}$. sp. tritic $i$ were detected in infected wheat leaves at $9 \mathrm{~h}$ after inoculation, when there were no visual symptoms (Figs. 6 and 7).

Standard curve of RT-PCR. The SYBR Green I for identifying $P$. striiformis f. sp. tritici was developed. Tenfold serial dilutions of DNA (0.1 ng to $1.0 \mathrm{fg})$ was used as a template. The standard curve was generated with a linear range covering $6 \log$ units. In Figure 8, the correlation coefficient of the standard curve in SYBR Green RT-PCR reached 0.99 and the amplification efficiency was $93.8 \%$. Furthermore, the amplification was specific as the curve melt and

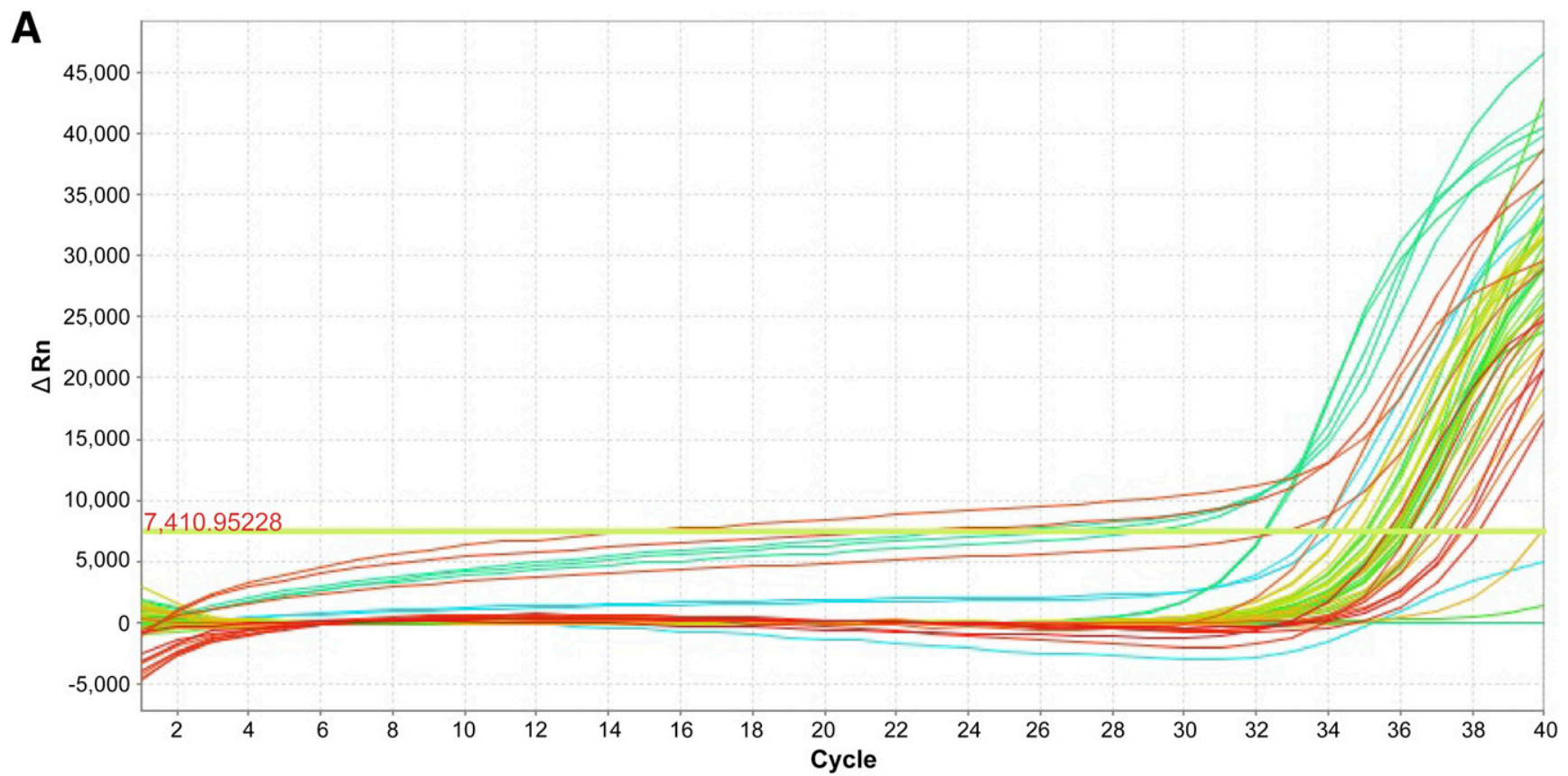

B

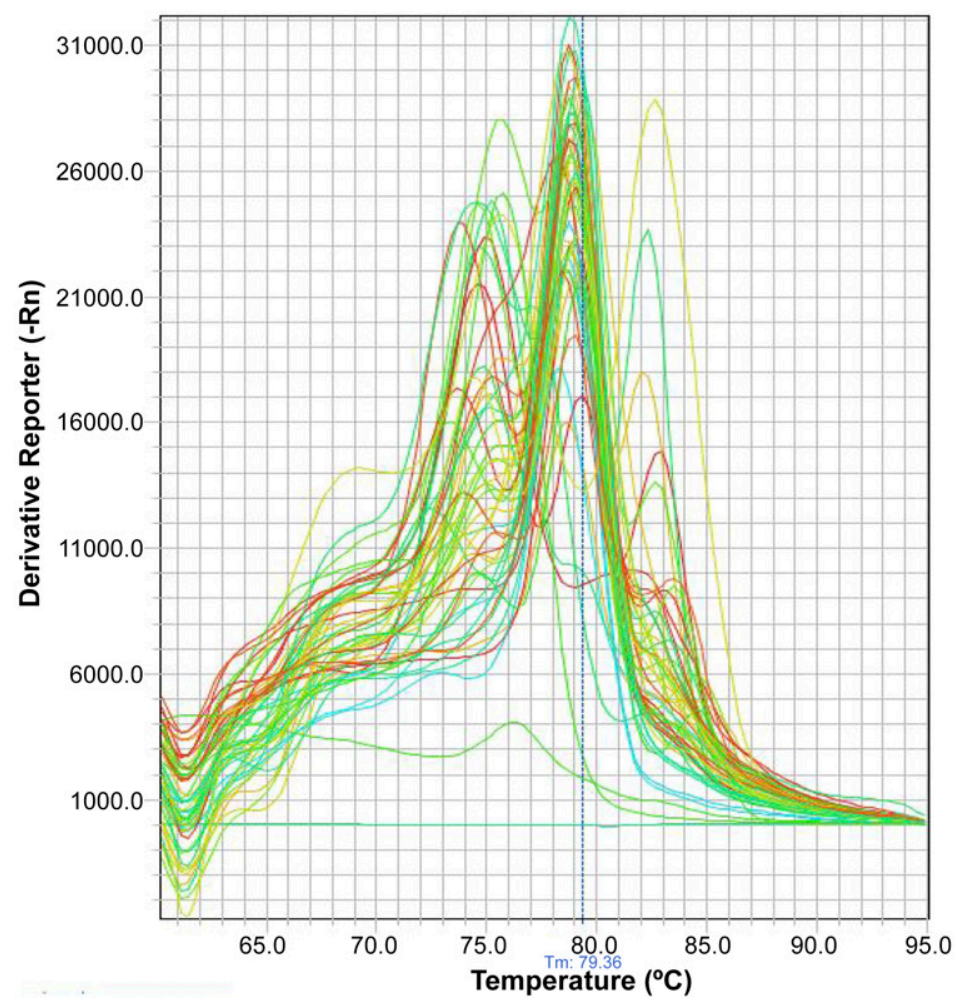

Fig. 9. Detection of $P$. striiformis f. sp. tritici from wheat at different growth stages using SYBR real-time PCR method. A, Real-time amplified curves the different color lines are the amplified curves of wheat DNA at different hours after inoculation. The black lines are negative controls. B, Melt curve of SYBR Green I (peak temperature at $79.34^{\circ} \mathrm{C}$ ). 
its detection sensitivity was $1.0 \mathrm{fg}$, showing that the SYBR Green RT-PCR was successful.

Identification of $P$. striiformis f. sp. tritici using the SYBR Green assay. The optimized SYBR $P$. striiformis $\mathrm{f}$. sp. tritici was detected from wheat samples after $6 \mathrm{~h}$ (Fig. 9). In contrast, no band was detected in the non-inoculated wheat samples.

\section{Discussion}

With rapid development of modern biotechnology, PCR amplification and RT-PCR have been widely used in detection of various plant pathogens. Application of these molecular biological techniques makes pathogen detection more simple and rapid. For $P$. striiformis f. sp. tritici, the PCR assay is especially faster than the conventional methods of uredinial observation used in identification and monitoring, because the latent period can be from a couple of weeks to several months, depending on the temperature (Chen 2005).

In this study, conserved sequences of $\mathrm{Bt} 2 \mathrm{a} / \mathrm{Bt} 2 \mathrm{~b}$ were used as primers for comparative PCR analysis of DNA from three distinct wheat rust pathogens. A specific PCR fragment was detected in P. striiformis f. sp. tritici, from which two sets of specific primers were designed, PSTF117/PSTR363 and TF144/TR323. Using the primer sets, specific SCAR markers of 237 and 180 bp of $P$. striiformis f. sp. tritici were obtained with the detection sensitivities of $1.0 \mathrm{pg} / \mu \mathrm{l}$ and 100.0 $\mathrm{fg} / \mu \mathrm{l}$ template DNA, respectively. In the detection of samples from different wheat-growing areas of China, the SCAR markers were consistently amplified from $P$. striiformis f. sp. tritici samples with no amplification from $P$. triticina, $P$. graminis f. sp. tritici, or other wheat fungal pathogens. These results demonstrate that the specific SCAR markers of $P$. striiformis $\mathrm{f}$. sp. tritici are highly reliable. Based on the markers, a molecular diagnosis and detection kit specifically for $P$. striiformis f. sp. tritici can be further developed and used to detect the pathogen in wheat plants before stripe rust symptoms and signs are observed in the fields.

After $P$. striiformis f. sp. tritici successfully infects wheat plants, it normally takes 9 to 15 days under optimal temperature conditions to produce new urediniospores (Chen 2005). Our greenhouse inoculation test showed that $P$. striiformis $\mathrm{f}$. sp. tritici-specific DNA fragment of 237 and $180 \mathrm{bp}$ can be detected $9 \mathrm{~h}$ after infection by PCR amplification with the specific SCAR markers. Therefore, PCR detection of $P$. striiformis f. sp. tritici can be conducted with leaf samples from fields during the latent period of infection. Early warning of wheat stripe rust can be made based on the detection of $P$. striiformis f. sp. tritici-specific SCAR markers. Early detection of the pathogen will facilitate early forecasting of rust disease epidemics and timely guidance of disease control, thus having great implications for reducing the costs in stripe rust management. Relative to common PCR, our SCAR markers can detect $P$. striiformis $\mathrm{f}$. sp. tritici $9 \mathrm{~h}$ after inoculation, which is much earlier than the previous reports (Cao et al. 2008; Wang et al. 2008). Furthermore, our SCAR markers can reach the detection limit of $1.0 \mathrm{pg} / \mu \mathrm{l}$ or $100.0 \mathrm{fg} / \mu \mathrm{l}$, indicating that it is more sensitive than the previous markers (Supplementary Fig. S3) (Cao et al. 2008; Pan et al. 2010; Wang et al. 2008). In contrast, Wang et al. (2008) reported that their SCAR marker could detect the pathogen in wheat leaves $24 \mathrm{~h}$ after inoculation with a detection limit of $10.0 \mathrm{pg} / \mu \mathrm{l}$, Pan et al. (2010) reported a SCAR marker with $10.0 \mathrm{pg} / \mu \mathrm{l}$ detection sensitivity, and Cao et al. (2008) reported that their SCAR marker could detect the fungus in wheat leaves 2 days after inoculation, with the detection limit of $10.0 \mathrm{pg} / \mu \mathrm{l}$.

The SYBR Green RT-PCR method was used in this study to quickly and accurately identify $P$. striiformis f. sp. tritici in infected leaves. The detection sensitivity of SYBR Green was $1.0 \mathrm{fg}$, equal to $10^{5} \mathrm{CN}$, more sensitive than a previous report of $100 \mathrm{fg}$ (Pan et al. 2010); and can detect the fungus $6 \mathrm{~h}$ after inoculation, earlier than the $12 \mathrm{~h}$ after inoculation in Pan's report.

In summary, we developed SCAR markers and a SYBR Green RT-PCR approach for quick and accurate detection of $P$. striiformis f. sp. tritici. The markers and the approach can be used to detect the pathogen from asymptomatic wheat samples with a high sensitivity. Early detection of the stripe rust pathogen in wheat leaves should contribute to timely control of the disease. In addition, the method could be used for quick evaluation of wheat germplasm for resistance to stripe rust. All of these applications should make monitoring of the disease and screening for host resistance more efficient.

\section{Acknowledgments}

This work was supported by National Natural Science Foundation (Grant No. 31571965), Beijing Natural Science Foundation (Grant No. L140012 and 6162022), Multidisciplinary Cooperation Project of Beijing Nova Program (Grant No. Z14111000180000), Beijing Nova Program (Grant No. Z131105000413057), Ministry of Agriculture, P. R. China (Grant No. CARS-03)

\section{Literature Cited}

Arif, M., Dobhal, S., Garrido, P. A., Orquera, G. K., Espíndola, A. S., Young, C. A., Ochoa-Corona, F. M., Marek, S. M., and Garzón, C. D. 2014. Highly sensitive end-point PCR and SYBR green qPCR detection of Phymatotrichopsis omnivora, causal fungus of cotton root rot. Plant Dis. 98:1205-1212.

Barnes, C. W., and Szabo, L. J. 2007. Detection and identification of four common rust pathogens of cereals and grasses using real-time polymerase chain reaction. Phytopathology 97:717-727.

Beck, J. J., and Ligon, J. M. 1995. Polymerase chain reaction assays for the detection of Stagonospora nodorum and Septoria tritici in wheat. Phytopathology 85:319-324.

Cao, L. H., Xu, S. C., Chen, W. Q., Liu, T. G., and Lin, R. M. 2007. Molecular diagnosis and detection of Puccinia triticina in China. Acta Phytophylactica Sin. 34:561-566

Cao, L. H., Xu, S. H., Lin, R. M., Liu, T. G., and Chen, W. Q. 2008. Early molecular diagnosis and detection of Puccinia striiformis f. sp. tritici in China. Lett. Appl. Microbiol. 46:501-506.

Chen, W. Q., Wellings, C., Chen, X., Kang, Z. S., and Liu, T. G. 2014. Wheat stripe (yellow) rust caused by Puccinia striiformis f. sp. tritici. Mol. Plant Pathol. 15:433-446.

Chen, W. Q., Wu, L. R., Liu, T. G., and Xu, S. C. 2009. Race dynamics, diversity, and virulence evolution in Puccinia striiformis f. sp. tritici, the causal agent of wheat stripe rust in China from 2003 to 2007. Plant Dis. 93:1093-1101.

Chen, X. M. 2005. Epidemiology and control of stripe rust Puccinia striiformis f. sp. tritici on wheat. Can. J. Plant Pathol. 27:314-337.

Demers, J. E., Crouch, J. A., and Castlebury, L. A. 2015. A multiplex real-time PCR assay for the detection of Puccinia horiana and P. chrysanthemi on chrysanthemum. Plant Dis. 99:195-200.

Fan, X., Zhang, J., Yang, L., Wu, M., Chen, W., and Li, G. 2015. Development of PCR-based assays for detecting and differentiating three species of Botrytis infecting broad bean. Plant Dis. 99:691-698.

Frederick, R. D., Snyder, K. E., Tooley, P. W., Berthier-Schaad, Y., Peterson, G. L., Bonde, M. R., Schaad, N. W., and Knorr, D. A. 2000. Identification and differentiation of Tilletia indica and T. walkeri using the polymerase chain reaction. Phytopathology 90:951-960.

Gao, L., Chen, W. Q., and Liu, T. G. 2008. The introduction of the detection methods of wheat rust. China Agricultural Science and Technology Press, Beijing.

Gao, L., Chen, W. Q., Liu, T. G., and Liu, B. 2013. An immunofluorescence assay for the detection of wheat rust species using monoclonal antibodies against urediniospores of Puccinia triticina. J. Appl. Microbiol. 115:1023-1028.

Glass, N. L., and Donaldson, G. C. 1995. Development of primer sets designed for use with the PCR to amplify conserved genes from filamentous ascomycetes. Appl. Environ. Microbiol. 61:1323-1330.

Johanson, A., Turner, H. C., McKay, G. J., and Brown, A. E. 1998. A PCR-based method to distinguish fungi of the rice sheath-blight complex, Rhizoctonia solani, $R$. oryzae and $R$. oryzae-sativae. FEMS Microbiol. Lett. 162:289294

Kutschera, U., and Hossfeld, U. 2012. Physiological phytopathology: origin and evolution of a scientific discipline. J. Appl. Bot. Food Qual. 85:1-5.

McCartney, H. A., Foster, S. J., Fraaije, B. A., and Ward, E. 2003. Molecular diagnostics for fungal plant pathogens. Pest Manag. Sci. 59:129-142.

Moricca, S., Ragazzi, A., Kasuga, T., and Mitchelson, K. R. 1998. Detection of Fusarium oxysporum f. sp. vasinfectum in cotton tissue by polymerase chain reaction. Plant Pathol. 47:486-494.

Mutasa, E. S., Chwarszczynska, D. M., and Asher, M. J. C. 1996. Single-tube, nested PCR for the diagnosis of Polymyxa betae infection in sugar beet roots and colorimetric analysis of amplified products. Phytopathology 86:493-497.

Pan, J. J., Luo, Y., Huang, C., Sun, Z. Y., Zhao, L., Yan, J. H., and Ma, Z. H. 2010 Application of real-time PCR to establish the quantitative detection of latent infection of wheat stripe rust quantity method. Acta Phytopathol. Sin. 40: 504-510.

Schilling, A. G., Moller, E. M., and Geiger, H. H. 1996. Polymerase chain reaction based assays for species-specific detection of Fusarium culmorum $F$. graminearum and $F$. avenaceum. Phytopathology 86:515-522.

Sreenivasaprasad, S., Sharada, K., Brown, A. E., and Mills, P. R. 1996. PCR-based detection of Colletotrichum acutatum of strawberry. Plant Pathol. 45:650-655.

Sun, G., Liu, J., Li, G., Zhang, X., Chen, T., Chen, J., Zhang, H., Wang, D., Sun, F., and Pan, H. 2015. Quick and accurate detection and quantification of 
Magnaporthe oryzae in rice using real-time quantitative polymerase chain reaction. Plant Dis. 99:219-224.

Villareál, L. M. M. A., Lannou, C., de Vallavieille-Pope, C., and Neema, C. 2002. Genetic variability in Puccinia striiformis $\mathrm{f}$. sp. tritici populations sampled on a local scale during natural epidemics. Appl. Environ. Microbiol. 68: 6138-6145.

Wan, A. M., Chen, X. M., and He, Z. H. 2007. Wheat stripe rust in China. Aust. J. Agric. Res. 58:605-619.

Wan, A. M., Zhao, Z. H., Chen, X. M., He, Z. H., Jin, S. L., Jia, Q. Z., Yao, G., Yang, J., Wang, B., Li, G., Bi, Y., and Yuan, Z. 2004. Wheat stripe rust 1139 epidemic and virulence of Puccinia striiformis f. sp. tritici in China in 2002. Plant Dis. 88:896-904
Wang, X. J., Chen, J. L., Buchenauer, H., Zhao, J., Han, Q. M., Huang, L. L., and Kang, Z. S. 2009. Detection of Puccinia striiformis in latently infected wheat leaves by nested polymerase chain reaction. J. Phytopathol. 157:490-493.

Wang, X. J., Zheng, W. M., Buchenauer, H., Zhao, J., Han, Q. M., Huang, L. L., and Kang, Z. S. 2008. The development of a PCR-based method for detecting Puccinia stiiformis latent infections in wheat leaves. Eur. J. Plant Pathol. 120: 241-247.

Wellings, C. R. 2011. Global status of stripe rust: a review of historical and 1160 current threats. Euphytica 179:129-141.

Willits, D. A., and Sherwood, J. E. 1999. Polymerase chain reaction detection of Ustilago hordei in leaves of susceptible and resistant barley varieties. Phytopathology 89:212-217. 